\title{
PERUBAHAN PENGGUNAAN LAHAN PERTANIAN KE NON PERTANIAN TAHUN 2012-2017 KECAMATAN KOTO TANGAH KOTA PADANG
}

\author{
Chairani Octavia \\ Program Studi Geografi, \\ Fakultas Ilmu Sosial, Universitas Negeri Padang \\ E-mail : chairani_octavia@yahoo.com
}

\begin{abstract}
ABSTRAK
Penelitian ini bertujuan untuk: (1) menganalisis seberapa luas perubahan penggunaan lahan di Kecamatan Koto Tangah, (2) menganalisis perubahan mata pencaharian petani di Kecamatan Koto Tangah, (3) menganalisis tingkat kesejahteraan petani di Kecamatan Koto Tangah. Jenis penelitian ini adalah kuantitatif dengan menggunakan teknik analisis overlay dan persentase. Data yang diperoleh dari BAPPEDA Kota Padang, BPS Kota Padang, dan Dinas Kehutanan Kota Padang. Hasil penelitian menemukan bahwa, (1) Pada tahun 2012 penggunaan lahan permukiman seluas $1.244 \mathrm{Ha}$ dan lahan pertanian seluas 7.746 Ha. Pada tahun 2017 lahan terbangun bertambah menjadi $1.478 \mathrm{Ha}$ dan lahan pertanian menjadi $3.154 \mathrm{Ha}$. Luas lahan terkonversi 5 tahun terakhir adalah luas lahan terbangun $1681.58 \mathrm{Ha}$ dan lahan pertanian $802.093 \mathrm{Ha}$. (2) mata pencaharian masyarakat sebelum adanya perubahan penggunaan lahan adalah petani sebanyak 52 orang, setelah adanya perubahan penggunaan lahan masyarakat mulai beralih ke pedagang sebanyak 15 orang dan 16 orang tetap menjadi petani. (3) tingkat kesejahteraan setelah perubahan penggunaan lahan berada pada tingkat sejahtera.
\end{abstract}

Kata kunci : perubahan lahan,mata pencaharian,tingkat kesejahteraan

\section{ABSTRACT}

This research aims are: (1) analyse how lenght land use change in Koto Tangah, (2) analyze changes in the livelihoods of farmers in Koto Tangah, (3) analyze the level of welfare of farmers in Koto Tangah. This type of research is a quantitative analysis by use of analytical techniques and the overlays percentage. Data obtained from BAPPEDA the city of Padang, Padang city, BPS and Forestry Padang city. The research found that the, (1) in the year 2012 land use settlement area of 1,244 Ha and farmland of 7,746 Ha. In the year 2017 awakened land increased to 1,478 Ha and farmland became 3,154 Ha. Conversion land area the last 5 years is land area woke up $1681.58 \mathrm{Ha}$ and 802,093 $\mathrm{Ha}$ of farmland. (2) the livelihoods of people prior to the land use change is a farmer as much as 52 people, After the land use change community began to switch to traders as much as 15 people and 16 people remain farmers. 3) levels of welfare after the change of land use are at the level of the prosperous.

Keywords: land use changed, livelihood, welfare 


\section{PENDAHULUAN}

Perubahan penggunaan lahan merupakan bentuk campur tangan manusia dalam memenuhi kebutuhan hidup baik materil maupun spiritual. Perubahan tersebut akan terus berlangsung dengan meningkatnya jumlah dan aktivitas penduduk dalam menjalankan kehidupan ekonomi, sosial dan budaya, yang pada akhirnya berdampak positif maupun negatif akibat perubahan penggunaan lahan tersebut. Seiring dengan pertambahan penduduk dan kegiatan pembangunan mengakibatkan semakin tinggi dan bertambahnya permintaan dan kebutuhan terhadap lahan yang dipergunakan untuk menyelenggarakan kegiatan, baik dari sektor pertanian maupun dari sektor non pertanian. Pesatnya laju pembangunan kota telah menyebabkan perubahan luas dalam pola penggunaan lahan dari kota-kota di sekitar desa.

Pertumbuhan penduduk di Kecamatan Koto Tangah pada tahun 2012 sebanyak 166.148 jiwa dan pada tahun 2017 sebanyak 182.296 jiwa, dalam kurun waktu 5 tahun terakhir penduduk di Kecamatan Koto Tangah bertambah sebanyak 16.148 jiwa (BPS Kota Padang 2017).

Perubahan penggunaan lahan di Kecamatan Koto Tangah dari tahun 2012 hingga 2017 mengalami perubahan, hal tersebut dapat dilihat dari meningkatnya luas permukiman yang ada. Bangunan bertambah luas sedangkan sawah mulai berkurang. Berkurangnya luas lahan pertanian akan berakibat pada perubahan pola penguasaan lahan pertanian terutama petani yang memiliki lahan usaha pertanian relatif sempit. Berkurangnya luas lahan pertanian yang merupakan sumber penghidupan masyarakat khususnya bagi para petani.

Peubahan lahan yang baru akan mempengaruhi kegiatan pertanian secara langsung. Perubahan disini dijelaskan lagi bahwa lahan pertanian bukan hanya sawah saja tetapi seperti irigasi (pengairan semi technical irrigation, pengairan non irrigation, non goverment dan tadah hujan) dan non pertanian (seperti tanah untuk bangunan dan pekarangan, tegal/ ladang/ kebun, kolam, tambak, dan rawa).

Dampak lain akibat pengurangan luas lahan pertanian adalah pendapatan menurun di sektor pertanian. Semakin berkurangnya lahan garapan dan kesempatan kerja di bidang pertanian menyebabkan pergeseran ataupun peralihan mata pencaharian penduduk dari pertanian ke non pertanian, seperti menjadi tukang ojek, buruh bangunan, dan pedagang asongan. Peralihan pekerjaan ke non pertanian yang dilakukan oleh petani serta semakin sempitnya lahan pertanian dikuasai oleh petani pada akhirnya akan berpengaruh pada tingkat kesejahteraan penduduk di Kecamatan Koto Tangah. 
Adapun tujuan diadakannya penelitian ini adalah:

1. Menganalisis seberapa luas perubahan penggunaan lahan di Kecamatan Koto Tangah.

2. Menganalisis perubahan mata pencaharian petani di Kecamatan Koto Tangah.

3. Menganalisis tingkat kesejahteraan petani di Kecamatan Koto Tangah.

\section{METODE PENELITIAN}

Jenis penelitian ini merupakan penelitian deskriptif kuantitatif. Penelitian deskriptif merupakan penelitian yang bertujuan untuk mengumpulkan informasi mengenai status suatu gejala yang ada yaitu keadaan gejala menurut apa adanya pada saat penelitian dilakukan (Arikunto, 2002).

Penelitian ini dilakukan pada bulan Mei sampai dengan Juli 2018. Lokasi penelitian dilakukan di Kecamatan Koto Tangah Kota Padang. Sesuai dengan tujuan yang ingin dicapai dan pembatasan masalah yang telah ditemukan pada bagian atas, bahwa untuk menentukan populasi didasarkan pada kepala kelurga petani yang mengalami alih fungsi lahan dari tahun 2012-2017. Kecamatan Koto Tangah terdiri dari 13 Kelurahan, 5 diantaranya yang memiliki lahan pertanian yaitu: Kelurahan Aia Pacah, Lubuk Minturun Sungai Lareh, Koto Pulai, Bungo Pasang, dan Koto Panjang Ikua Koto.

Responden dari penelitian ini adalah petani yang mengalami perubahan penggunaan lahan. Terdapat 1.450 petani yang tersebar di 5 kelurahan yang ada. Berdasarkan jumlah populasi petani yang ada di 5 kelurahan, teknik penentuan sampel menggunakan metode acak sederhana (simple random sampling) ditentukan dengan rumus (Sugiarto, 2003).

$$
\mathrm{n}=\frac{\mathrm{NZ} Z^{2}}{\mathrm{~N} \delta^{2}+\mathrm{Z}^{2} \sigma}
$$

Keterangan :

$$
\begin{array}{ll}
\mathrm{n} & =\text { Ukuran sampel } \\
\mathrm{N} & =\text { Ukuran petani }(1.450) \\
\mathrm{Z} & =\text { Derajat kepercayaan } \mathrm{Z}(90 \%=1,645) \\
\sigma^{2} & =\text { Varian sampel }(5 \%=0,05) \\
\delta^{2} & =\text { Standar deviasi }(5 \%=0,05)
\end{array}
$$

Sehingga diperoleh:

$$
\begin{aligned}
& \mathrm{n}=\underline{1.450 \times(1,645)^{2} \times 0.05} \\
& \left(1.450 \times(0.05)^{2}\right)+\left(1,645^{2} \times\right. \\
& 0,05) \\
& =\underline{196.48} \\
& 3.77 \\
& =52.11=52 \text { orang }
\end{aligned}
$$

Berdasarkan perhitungan dengan menggunakan rumus di atas, maka diperoleh jumlah responden sebagai sampel sebanyak 52 petani dengan teknik proportional random sampling. Jumlah sampel tersebut dapat ditentukan alokasi proporsi sampel dengan rumus : 


$$
\mathrm{n}_{\mathrm{a}}=\frac{N a}{N} \times n
$$

Keterangan :

$$
\begin{aligned}
& \mathrm{n}_{\mathrm{a}}=\text { Ukuran sampel petani } \\
& \mathrm{N}_{\mathrm{a}}=\text { Ukuran petani keseluruhan } \\
& \mathrm{n}=\text { Ukuran sampel petani keseluruhan } \\
& \mathrm{N}=\text { Ukuran petani keseluruhan }
\end{aligned}
$$

$$
\text { Berdasarkan rumus }
$$

perhitungan di atas, maka pengambilan ukuran sampel petani responden pada masing-masing kelompok tani dapat dilihat pada Tabel 1 berikut: 
Tabel 1 Sebaran Sampel Penelitian Per KK Petani

\begin{tabular}{|c|c|c|c|}
\hline No & Pekerjaan & $\begin{array}{l}\text { Jumlah } \\
\text { KK }\end{array}$ & Jumlah Sampel \\
\hline 1 & Aia Pacah & 348 & 13 \\
\hline 2 & $\begin{array}{l}\text { Lubuk Minturun } \\
\text { Sungai Lareh }\end{array}$ & 167 & 6 \\
\hline 3 & Bungo Pasang & 153 & 5 \\
\hline 4 & $\begin{array}{l}\text { Koto Panjang } \\
\text { Ikua Koto }\end{array}$ & 477 & 17 \\
\hline 5 & Koto Pulai & 305 & 11 \\
\hline \multicolumn{2}{|r|}{ Jumlah } & 1.450 & 52 \\
\hline
\end{tabular}

Sumber: Camat Koto Tangah (2018)

Teknik analisis data menggunakan data luas perubahan lahan, perubahan mata pencaharian, dan tingkat ksejahteraan, berikut penjelasannya:

1. Luas Perubahan Lahan

Teknik overlay merupakan lahan/landscape. Analisis overlay ini juga dimaksudkan untuk melihat deskripsi kegiatan ekonomi yang potensial berdasarkan kriteria pertumbuhan dan kriteria kontribusi. Teknik overlay ini dibentuk melalui penggunaan secara tumpang tindih (seri) suatu peta yang masing-masing mewakili faktor penting lingkungan/ lahan.

2. Perubahan mata Pencaharian

Data yang telah diperoleh dari lapangan baik melalui wawancara dan angket diolah dengan memekai formula sebagai berikut:

Keterangan:

$$
\mathrm{P}=\frac{f}{n} \times 100 \%
$$

$$
\begin{aligned}
& \mathrm{P}=\text { Pesentase } \\
& f=\text { Frekuensi Jawaban }
\end{aligned}
$$

$n=$ Jumlah Responden

(Arikunto, 2002)

3. Tingkat Kesejahteraan

Alat analisis yang digunakan untuk mengukur tingkat kesejahteraan petani menggunakan tujuh indikator Badan Pusat statistik (2014) yang meliputi kependudukan, kesehatan dan gizi, pendidikan, ketenagakerjaan, taraf dan pola konsumsi, perumahan dan lingkungan, sosial dan lain-lain. Klasifikasi kesejahteraan yang digunakan terdiri dari dua klasifikasi yaitu rumah tangga sejahtera dan belum sejahtera. Variabel pengamatan disertai dengan klasifikasi dan skor yang dapat mewakili besaran klasifikasi indikator tersebut. Skor tingkat klasifikasi tujuh indikator kesejahteraan dihitung berdasarkan pedoman penentuan Range Skor.

Rumus penentuan range skor adalah :

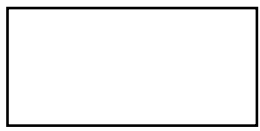




$$
\mathrm{RS}=\frac{S k T-S k R}{J K I}
$$

Dimana :

$\mathrm{RS}=$ Range skor

SkT $=$ Skor tertinggi

SkR $=$ Skor terendah

$\mathrm{JKl}=$ Jumlah klasifikasi yang digunakan

Jumlah skor diperoleh dari informasi hasil skor mengenai kependudukan, kesehatan dan gizi, pendidikan, ketenagakerjaan, taraf dan pola konsumsi, perumahan dan lingkungan, sosial dan lain-lain. Dari penskoran kemudian dilihat interval skor dari dua katagori klasifikasi diatas yaitu rumah tangga sejahterah dan belum sejahtera.

\section{HASIL DAN PEMBAHASAN}

a. Hasil

a. Luas Perubahan Penggunaan Lahan

Berikut disajikan perubahan luas penggunaan lahan dari tahun 2017 di Kecamatan Koto Tangah Kota Padang. Perubahan luas penggunaan lahan bisa dilihat pada tabel 2 di bawah ini:

Tabel 2 Jenis Penggunaan Lahan

\begin{tabular}{|c|c|c|c|c|}
\hline \multirow[t]{2}{*}{ No } & \multirow[t]{2}{*}{ Jenis Penggunaan Lahan } & \multicolumn{2}{|c|}{ Luas Lahan (Ha) } & \multirow{2}{*}{$\begin{array}{l}\text { Luas Lahan } \\
\text { Terkonversi }\end{array}$} \\
\hline & & 2012 & 2017 & \\
\hline 1 & Hutan Primer & 11.810 & 10.178 & 911.154 \\
\hline 2 & Hutan Sekunder & 762 & 5.404 & 7011.49 \\
\hline 3 & Lahan Terbangun & 1.244 & 1.478 & 1681.58 \\
\hline 4 & Lahan Pertanian & 7.746 & 3.154 & 802.093 \\
\hline 5 & Semak & 948 & 1.733 & 16.7785 \\
\hline 6 & Tubuh Air & 59 & 1.143 & - \\
\hline & Jumlah & 14.783 & 12.912 & 27.695 \\
\hline
\end{tabular}

Sumber: Pengolahan Data Primer 2018

Berdasarkan hasil observasi dan uraian tabel, dapat diketahui bahwa luas lahan pertanian mengalami perubahan. Pada tabel dapat dilihat pada tahun 2012 penggunaan lahan permukiman seluas 1.244 Ha dan lahan pertanian seluas 7.746 Ha. Dan pada tahun 2017 lahan terbangun bertambah menjadi $1.478 \mathrm{Ha}$ dan lahan pertanian menjadi $3.154 \mathrm{Ha}$. Luas lahan terkonversi 5 tahun terakhir adalah luas lahan terbangun $1681.58 \mathrm{Ha}$ dan lahan pertanian 802.093 Ha. Menurut UU RI No 41 tahun 2009 tentang Perlindungan Lahan Pertanian Pangan Berkelanjutan telah mengatur larangan alih fungsi lahan pertanian, apalagi lahan pertanian sangat produktif. Sangat disayangkan sekali laha pertanian yang produktif dimatikan dengan menumbuhkan bangunanbangunan di atasnya.

Perubahan penggunaan lahan yang terjadi di Kecamatan Koto Tangah ini semakin berkembang pesat setelah terjadi gempa besar yang melanda Kota Padang pada tahun 2008 silam. Sejak saat itulah para pemborong lahan mulai berlomba mencari lahan yang memungkinkan untuk dibangun perumahan dan semacamnya.

b. Orientasi Mata Pencaharian

Berikut disajikan perubahan mata pencaharian petani pokok sebelum adanya perubahan penggunaan lahan di 
Kecamatan Koto Tangah Kota Padang. Perubahan luas penggunaan lahan bisa dilihat pada tabel 3 di bawah ini.

Tabel 3 Mata Pencaharian Sebelum dan Setelah Konversi Lahan

\begin{tabular}{cccccc}
\hline $\begin{array}{c}\text { N } \\
\mathbf{0}\end{array}$ & Pekerjaan & $\mathbf{f}$ & $\boldsymbol{\%}$ & $\mathbf{f}$ & $\boldsymbol{\%}$ \\
\hline $\mathbf{1}$ & Petani & & & & \\
& & $\mathbf{5}$ & $\mathbf{1 0}$ & 1 & 3 \\
& 1. & $\mathbf{2}$ & $\mathbf{0}$ & 6 & 1 \\
& & & & 1 & 2 \\
& 2. Kedagang & & & 5 & 9 \\
& & & & 8 & 1 \\
& 3. Jasyawa & & & & 5 \\
& & & & 1 & 2 \\
& & & & 3 & 5 \\
\hline
\end{tabular}

Sumber: Pengolahan Data Primer 2018

Dari data mata pencaharian masyarakat sebelum konversi lahan terdapat 52 responden yang bekerja sebagai petani. Setelah adanya perubahan penggunaan lahan yang memilih tetap sebagai petani sebanyak 16 orang (31\%), dan 36 responden lainnya memilih untuk berpindah profesi sebagai pedagang 15 orang (29\%), Karyawan 8 orang (15\%), dan Jasa 13 orang (25\%).

Pekerjaan sebagai petani sebenarnya tidak dapat menutupi kebutuhan sehari-hari, untuk memenuhi semua kebutuhan yang ada banyak petani melakukan pekerjan diluar pokok mereka. Banyak dari mereka bekerja sebagai buruh, jasa maupun menjadi pedagang kecil, pekerjaan ini biasanya dikerjaan oleh para ibu rumah tanggga.
Untuk melihat tabel pekerjaan sampingan sebelum adanya perubahan penggunaan lahan dapat dilihat pada tabel 4 berikut:

Tabel 4 Mata Pencaharian Sampingan Sebelum Konversi

\begin{tabular}{|c|c|c|c|}
\hline No & Pekerjaan & $\mathbf{f}$ & $\%$ \\
\hline 1 & Petani & 16 & 31 \\
\hline 2 & Buruh & 14 & 27 \\
\hline 3 & Jasa & 13 & 25 \\
\hline 4 & Pedagang & 9 & 17 \\
\hline & Jumlah & \multicolumn{2}{|c|}{52} \\
\hline & $\%$ & \multicolumn{2}{|c|}{100} \\
\hline
\end{tabular}

Sumber: Pengolahan Data Primer 2018

Dari data mata pencaharian sampingan masyarakat sebelum konversi lahan yang berprofesi sebagai petani sebanyak 16 orang (31\%), buruh 14 orang (27\%), jasa 13 orang (25\%), dan pedagang 9 orang (17\%). Setelah adanya konversi lahan pekerjaan sampingan masyarakatpun mulai berubah, bisa dilihat pada tabel 5 dibawah:

Tabel 5 Mata Pencaharian

Sampingan Setelah Konversi

\begin{tabular}{|c|c|c|c|}
\hline No & Pekerjaan & $\mathbf{f}$ & $\%$ \\
\hline 1 & Petani & 12 & 23 \\
\hline 2 & Buruh & 9 & 17 \\
\hline 3 & Jasa & 16 & 31 \\
\hline 4 & Pedagang & 15 & 29 \\
\hline & Jumlah & \multicolumn{2}{|c|}{52} \\
\hline & $\%$ & \multicolumn{2}{|c|}{100} \\
\hline
\end{tabular}

Sumber: Pengolahan Data Primer 2018

Dari data mata pencaharian sampingan masyarakat setelah konversi lahan yang berprofesi sebagai petani sebanyak 12 orang (23\%), buruh 9 
orang (17\%), jasa 16 orang (31\%), dan pedagang 15 orang (29\%).

Mata pencaharian pokok masyarakat Kecamatan Koto Tangah sebelum alih fungsi lahan pertanian adalah bertani, dulunya daerah ini banyak digunakan untuk bercocok tanam, ladang dan kebun. Kecamatan Koto Tangah termasuk lahan produktif di Kota Padang, tapi karena satu dan lain hal banyak petani yang menjual sawah mereka demi menyambung hidup.

Pengalihan tersebut dipengaruhi oleh beberapa faktor antara lain, (1) desakan ekonomi (biaya pendidikan dan kebutuhan sehari-hari), (2) faktor kepemilikan lahan yang mengandung budaya, seperti harta warisan (harta pusaka rendah), untuk menghindari pertikaian antar anggota keluarga maka tanah itu dijual kemudian hasilnya dibagi sama rata pada seluruh anggota keluarga agar terhindari dari pertikaian, dengan letak tanah yang strategis, banyak para pemborong lahan ingin mendirikan perumahan di lahan pertanian terlebih setelah adanya gempa beberapa waktu yang lalu.

Mata pencaharian sampingan Kecamatan Koto Tangah sebelum dan sesudah pengalihan pengunaan lahan sangat beragam adanya. Sebenarnya pekerjaan buruhlah yang sering banyak ditemui, jenis buruh ini banyak jenisnya ada buruh bangunan, buruh tani, dan buruh harian lepas (serabutan). Pekerjaan sampingan ini dilakukan karena tidak tercukupinya kebutuhan sehari-hari. Perubahan mata pencaharian ini banyak terjadi di seluruh kelurahan yang ada di
Kecamatan Koto Tangah, terlebih terjadi pada kawasan kampus, perumahan dan sekolah.

Selanjutnya mata pencaharian sampingan masyarakat di 5 kelurahan yang ada di Kecamatan Koto Tangah setelah adanya pengalihan fungsi lahan pertanian menjadi lahan non pertanian yaitu berdagang. Pekerjaan ini diminati oleh masyarakat karena tidak memerlukan tenaga yang bnayak dan waktu yang terbilang mudah untuk dilakukan.

Dampak alih fungsi lahan pertanian menjadi lahan non pertanian terhadap mata pencaharian di Kecamatan Koto Tangah yaitu terjadi perubahan mata pencaharian pokok masyarakat, karena lahan yang ingin di garap tidak ada lagi. Jadi hal ini sangat mempengaruhi masyarakat tani, mereka mencari pekerjaan lain untuk tetap bisa memenuhi kebutuhan seluruh anggota keluarga, dan karena hal ini juga terjadi peningkatan mata pencaharian sampingan.

Perubahan mata pencaharian masyarakat dari suatu sistem ke sistem yang lain terjadi karena peningkatan pengetahuan serta ketersediaan waktu dan kesempatan untuk meningkatkan produktivitas.

Kesimpulannya sesudah terjadinya alih fungsi lahan pertanian banyak keluarga tani yang beralih profesi untuk memenuhi kebutuhan keluarga karena sawah yang mereka miliki berkurang, dan berpikir tidak bisa lagi menopang kebutuhan ekonomi yang semakin lama semakin bertambah.

c. Tingkat Kesejahteraan 
Untuk melihat tingkat kesejahteraan masyarakat bisa dilihat dari segi pendapatan masyarakat Kecamatan Koto Tangah. Mengenai pendapatan masyarakat Kecamatan Koto Tangah setelah alih fungsi lahan dapat dilihat pada tabel 6 berikut

Tabel 6 Pendapatan Pokok Setelah Konversi

\begin{tabular}{|c|c|c|c|c|c|c|c|}
\hline \multirow[t]{2}{*}{ No } & \multirow[t]{2}{*}{ Pendapatan } & \multirow[t]{2}{*}{ Petani } & \multirow[t]{2}{*}{ Pedagang } & \multirow[t]{2}{*}{ Jasa } & \multirow[t]{2}{*}{ Karyawan } & \multicolumn{2}{|c|}{ Jumlah } \\
\hline & & & & & & $\mathbf{f}$ & $\%$ \\
\hline 1 & Rp. 450.000-Rp.600.000 & & 1 & 1 & & 2 & 4 \\
\hline 2 & Rp.650.000-Rp.800.000 & & 3 & 4 & & 7 & 14 \\
\hline 3 & $\begin{array}{l}\text { Rp. 850.000- } \\
\text { Rp.1.000.000 }\end{array}$ & 9 & 5 & 5 & & 19 & 36 \\
\hline 4 & $\begin{array}{l}\text { Rp.1.500.000- } \\
\text { Rp.3.000.000 }\end{array}$ & 7 & 6 & 3 & 8 & 24 & 46 \\
\hline & Total & & & & & & 52 \\
\hline & $\%$ & & & & & & 100 \\
\hline
\end{tabular}

Sumber: Pengolahan Data Primer 2018

Pada tabel 6 pendapatan pokok masyarakat sebelum adanya konversi lahan sangat beragam. Namun setelah perubahan penggunaan lahan pendapatan berada pada Rp.450.000 Rp.600.000 sebanyak 2 orang, Rp.650.000 - Rp.800.000 sebanyak 7 orang, Rp.850.000 - Rp.1.000.000 sebanyak 19 orang dan pendapatan dengan rata-rata Rp.1.500.000 Rp.3.000.000 sebanyak 24 orang.

Untuk melihat lebih jelas mengenai pendapatan pokok masyarakat tani di Kecamatan Koto Tangah sebelum konversi dapat dilihat pada grafik 1 di bawah ini:

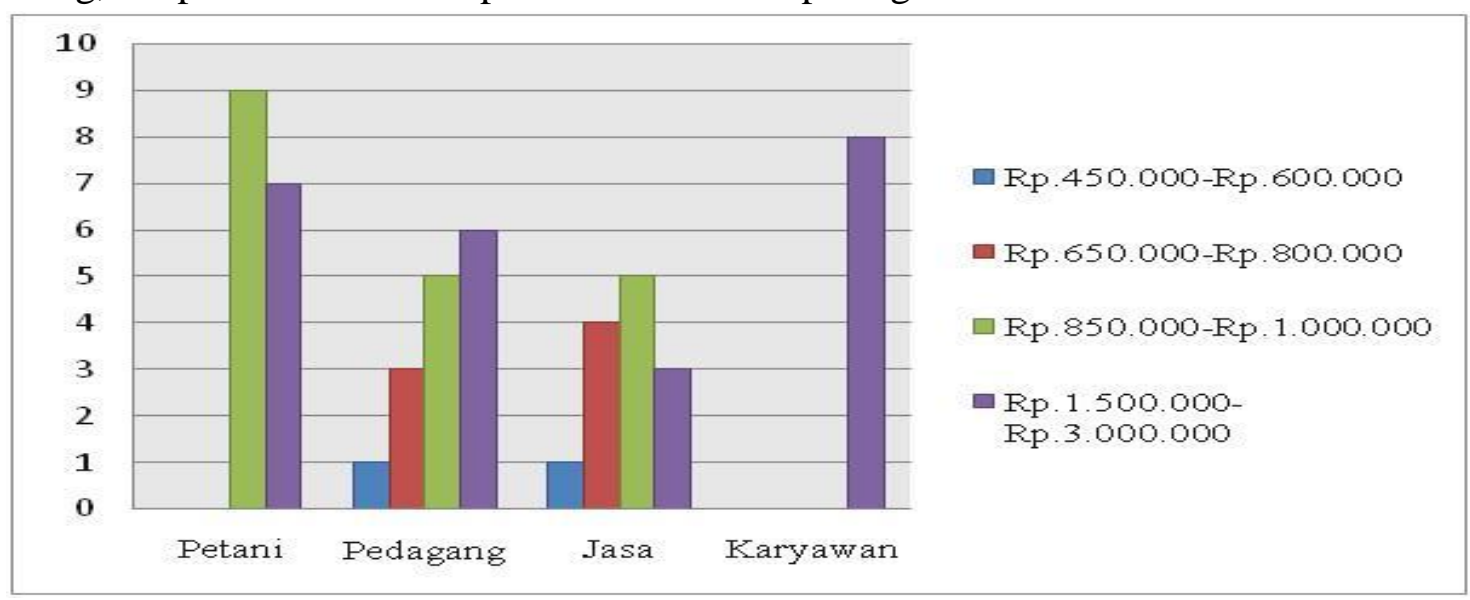

Grafik 1 Pendapatan Pokok Setelah Konversi

Sumber: Pengolahan Data Primer 2018

Dengan ini bisa disimpulkan bahwa setelah adanya konversi lahan masyarakat memiliki pendapatan rata- rata Rp.850.000 - Rp1.000.000 dan Rp.1.500.000 - Rp.3.000.000. Hal ini 
dikarenakan masyarakat pada umumya berprofesi sebagai pedagang.

Untuk melihat pendapatan sampingan petani di Kecamatan Koto
Tangah pada 5 kelurahan yang ada, bisa dilihat pada tabel 7 berikut:

Tabel 7 Pendapatan SampinganSebelum Konversi

\begin{tabular}{|c|c|c|c|c|c|c|c|}
\hline \multirow[t]{2}{*}{ No } & \multirow[t]{2}{*}{ Pendapatan } & \multirow[t]{3}{*}{ Petani } & \multirow[t]{2}{*}{ Pedagang } & \multirow[t]{2}{*}{ Buruh } & \multirow[t]{2}{*}{ Jasa } & \multicolumn{2}{|c|}{ Jumlah } \\
\hline & & & & & & $\mathbf{f}$ & $\%$ \\
\hline 1 & $\begin{array}{l}\text { Rp. } 450.000- \\
\text { Rp. } 600.000\end{array}$ & & 2 & 6 & 3 & 11 & 21 \\
\hline 2 & $\begin{array}{l}\text { Rp.650.000- } \\
\text { Rp.800.000 }\end{array}$ & 5 & 3 & 5 & 4 & 15 & 29 \\
\hline 3 & $\begin{array}{l}\text { Rp. 850.000- } \\
\text { Rp.1.000.000 }\end{array}$ & 8 & 3 & 1 & 3 & 17 & 33 \\
\hline 4 & $\begin{array}{l}\text { Rp.1.500.000- } \\
\text { Rp.3.000.000 }\end{array}$ & 3 & 1 & & 3 & 7 & 14 \\
\hline & Jumlah & & & & & & 52 \\
\hline & $\%$ & & & & & & 100 \\
\hline
\end{tabular}

Sumber : Pengolahan Data Primer 2018

Pada tabel 7 pendapatan dengan rata-rata Rp.1.500.000 - Rp. sampingan sebelum adanya konversi 3.000.000 sebanyak 7 orang.

Untuk melihat lebih jelas lahan berada pada rata-rata Rp.450.000 - Rp.600.000 sebanyak 11 orang, mengenai pendapatan sampingan petani Rp.650.000 - Rp.800.000 sebanyak 15 di Kecamatan Koto Tangah sebelum orang, Rp.850.000 - Rp.1.000.000 konversi dapat dilihat pada grafik 2 di sebanyak 17 orang dan pendapatan bawah ini:

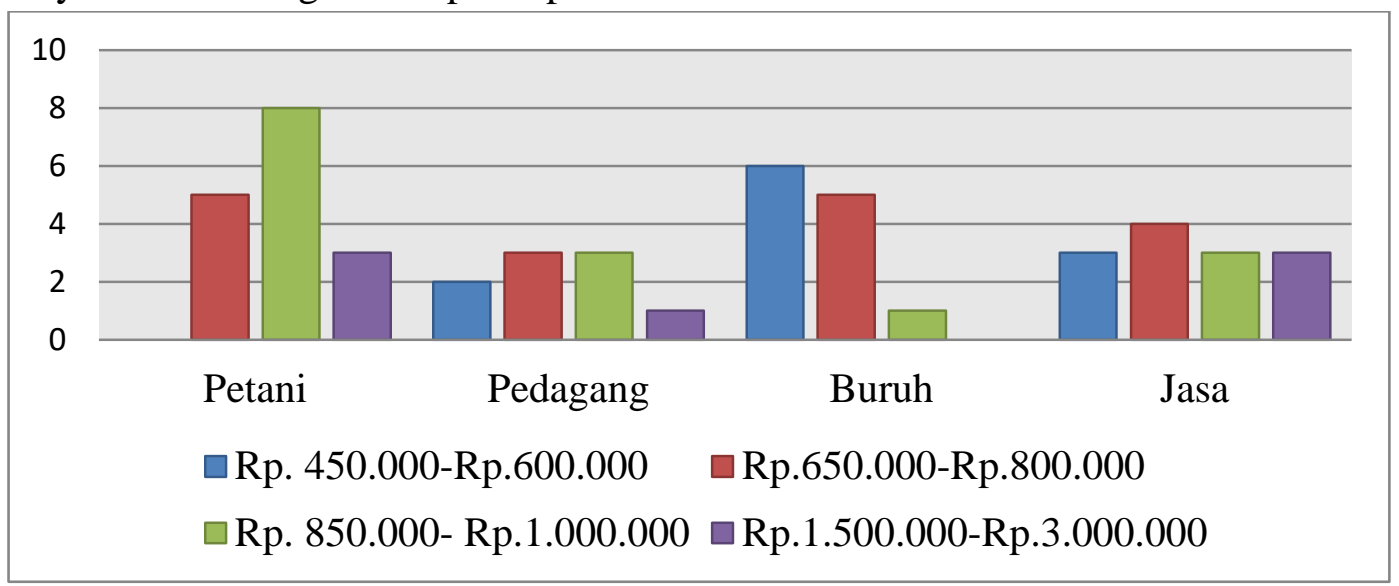

Grafik 2 Pendapatan Sampingan Sebelum Konversi

Sumber: Pengolahan Data Primer 2018

Dengan ini bisa disimpulkan bahwa sebelum adanya konversi lahan masyarakat memiliki pendapatan ratarata Rp.450.000-Rp.600.000 dan 
Rp.8500.000-Rp.1.000.000. Hal ini dikarenakan masyarakat pada umumya berprofesi sebagai petani dan buruh.
Untuk melihat perubahan pendapatan sampingan setelah adanya perubahan penggunaan lahan dapat dilihat pada tabel 8 berikut:

Tabel 8 Pendapatan Sampingan Setelah Konversi

\begin{tabular}{rlccccc}
\hline No & \multicolumn{1}{c}{ Pendapatan } & $\begin{array}{c}\text { Petan } \\
\mathbf{i}\end{array}$ & $\begin{array}{c}\text { Pedagan } \\
\mathbf{g}\end{array}$ & Jasa & $\begin{array}{c}\text { Buru } \\
\mathbf{h}\end{array}$ & $\begin{array}{c}\text { Jumla } \\
\mathbf{h}\end{array}$ \\
\hline $\mathbf{1}$ & $\begin{array}{l}\text { Rp. } 450.000- \\
\text { Rp.600.000 }\end{array}$ & & 1 & 1 & 7 & 9 \\
$\mathbf{2}$ & $\begin{array}{l}\text { Rp.650.000- } \\
\text { Rp.800.000 }\end{array}$ & 3 & 4 & 5 & 3 & 15 \\
$\mathbf{3}$ & $\begin{array}{l}\text { Rp. } 850.000- \\
\text { Rp.1.000.000 }\end{array}$ & 5 & 7 & 5 & 1 & 15 \\
$\mathbf{4}$ & $\begin{array}{l}\text { Rp.1.500.000- } \\
\text { Rp.3.000.000 } \\
\text { Total } \\
\mathbf{\%}\end{array}$ & 4 & 5 & 4 & & 13 \\
& & & & & & $\mathbf{5 2}$ \\
\hline
\end{tabular}

Sumber:Pengolahan Data Primer 2018

Pada tabel 8 pendapatan sampingan setelah adanya konversi lahan berada pada rata-rata $\mathrm{Rp} .450 .000$ Rp.600.000 sebanyak 9 orang, Rp.650.000-Rp.800.000 sebanyak 15 orang, Rp.850.000-Rp.1.000.000 sebanyak 15 orang dan pendapatan dengan rata-rata Rp.1.500.000-Rp. 3.000.000 sebanyak 13 orang.

Untuk melihat lebih jelas mengenai pendapatan sampingan petani di Kecamatan Koto Tangah sebelum konversi dapat dilihat pada grafik 3 di bawah ini:

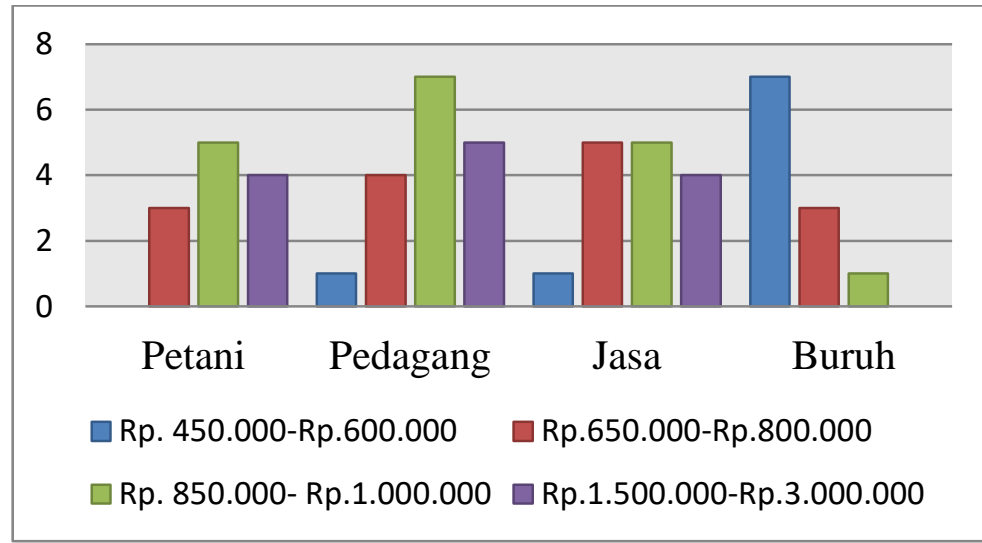

\section{Grafik 3 Pendapatan Sampingan Setelah Konversi}

Sumber: Pengolahan Data Primer 2018

Dengan ini bisa disimpulkan bahwa setelah adanya konversi lahan masyarakat memiliki pendapatan rata- rata Rp.650.000-Rp.800.000 dan Rp.8500.000-Rp.1.000.000. Hal ini 
dikarenakan masyarakat pada umumya berprofesi sebagai petani dan buruh.

\section{Tabel 9 Total Pendapatan}

\begin{tabular}{llll}
\hline No & Pendapatan & $\mathrm{f}$ & $\%$ \\
Tingkat & kesejahteraan rumah \\
tangga dalam & penelitian ini adalah \\
menggunakan & konsep BPS yang \\
mencakup 14 & indikator pengukuran \\
rumah tangga sejahtera. Menghitung & jawaban tiap-tiap indikator \\
jumlah jawaban \\
dengan rentang nilai atau range sebagai \\
berikut:
\end{tabular}

Keluarga Sejahtera $=9-14$

Keluarga Tidak Sejahtera $=1-8$

Berdasarkan hasil penelitian, menunjukkan bahwa keseluruhan petani dalam penelitian ini adalah sejahtera. Jadi, mayoritas petani dapat memenuhi indikator-indikator tingkat kesejahteraan menurut BPS tahun 2005.

2. Pembahasan

Kesatu: Tanah (soil) adalah bagian dari bentang alam (Iandscape) yang fisiknya meliputi pengertian lngkungan fisik seperti tanah, iklim, topografi/relief, hidrologi dan vegetasi alami (natural vegetation) dimana secara potensial akan berpengaruh terhadap penggunaan lahan (Eirlangga, 2007).Berdasarkan hasil penelitian perubahan penggunaan lahan pertanian menjadi non pertanian di Kecamatan Koto Tangah Kota padang, maka diperoleh gambaran bahwa telah banyak perubahan penggunaan lahan pertanian menjadi lahan non pertanian dalam rentang tahun 5 tahun terakhir yaitu dari tahun 2012-2017. Ini disebabkan karena adanya peningkatan pertambahan penduduk setiap tahunnya, sedangkan

\begin{tabular}{|cccc|}
\hline 1 & $<$ Rp. 2.100 .000 & 25 & 25 \\
2 & Rp.2.100.000 & 24 & 46 \\
3 & $>$ Rp.2.100.000 & 15 & 29 \\
& Jumlah & $\mathbf{5 2}$ & $\mathbf{1 0 0}$
\end{tabular}

Sumber: Pengolahan Data Primer 2018

lahan yang diperuntukan untuk pembanguan lahan terbangun tidak memadai. Sehingga untuk mensiasati itu semua dilakukan pembangunan di area pertanian.

Kedua: Perubahan adalah keadaan berubah, peralihan, pertukaran. Sedangkan mata pencaharian merupakan pekerjaan yang menjai pokok penghidupan (sumbu atau pokok), pekerjaan/pencaharian utama yang di kerjakan untuk biaya sehari-hari. Mata pencaharian adalah segala kegiatan yang dilakukan untuk menghasilkan pendapatan guna memenuhi kebutuhan manusia (Fuzah, 2009).

Kesimpulannya sesudah terjadinya alih fungsi lahan pertanian banyak keluarga tani yang beralih profesi untuk memenuhi kebutuhan keluarga karena sawah yang mereka miliki berkurang, dan berpikir tidak bisa lagi menopang kebutuhan ekonomi yang semakin lama semakin bertambah.

Ketiga: Kesejahteraan merupakan sejumlah kepuasan yang diperoleh seseorang dari hasil mengkonsumsi pendapatan yang diterima, namun tingkatan kesejahteraan itu sendiri merupakan sesuatu yang bersifat relatif karena tergantung dari besarnya kepuasan yang diperoleh dari hasil mengkonsumsi pendapatan tersebut. 
Berdasarkan hasil penelitian, menunjukkan bahwa keseluruhan petani dalam penelitian ini adalah sejahtera. Jadi, Mayoritas petani dapat memenuhi indikator-indikator tingkat kesejahteraan menurut BPS tahun 2005.

\section{PENUTUP}

\section{Simpulan}

Sesuai dengan deskripsi data dan pembahasan yang dikemukakan pada bab sebelumnya, maka dapat disimpulkan hal-hal sebagai berikut:

a. Perubahan penggunaan lahan pertanian menjadi non pertanian di Kecamatan Koto Tangah Kota Padang, maka diperoleh gambaran bahwa telah banyak perubahan penggunaan lahan pertanian menjadi lahan non pertanian dalam rentang tahun 5 tahun terakhir yaitu dari tahun 2012-2017. Pada tahun 2012 penggunaan lahan permukiman seluas $1.244 \mathrm{Ha}$ dan lahan pertanian seluas $7.746 \mathrm{Ha}$. Dan pada tahun 2017 lahan terbangun bertambah menjadi 1.478 Ha dan lahan pertanian menjadi 3.154 Ha. Luas lahan terkonversi 5 tahun terakhir adalah luas lahan terbangun $1681.58 \mathrm{Ha}$ dan lahan pertanian 802.093. HaI ini disebabkan karena adanya peningkatan pertambahan penduduk setiap tahunnya, sedangkan lahan yang diperuntukan untuk pembanguan lahan terbangun tidak memadai. Sehingga untuk mensiasati itu semua dilakukan pembangunan di area pertanian.

b. Perubahan mata pencaharian pokok maupun mata pencaharian sampingan, yang berubah sebelum ataupun sesudah adanya perubahan penggunaan lahan di Kecamatan Koto Tangah. Sebelum adanya perubahan penggunaan lahan banyak masyarakat yang berprofesi sebagai Petani sebanyak 52 orang, namun setelah adanya perubahan penggunaan lahan masyarakat banyak memilih pekerjaan sebagai pedagang sebanyak 15 orang dengan alasan tidak membutuhkan tenaga yang banyak dan sebanyak 16 orang tetap sebagai petani.

c. Setelah adanya perubahan penggunaan lahan, dilihat pula dari segi pendapatan masyarakat yang mulai merangkak naik, kesejahteran masyarakatpun mulai berubah. Tingkat kesejahteraan masyarakat di Kecamatan Koto Tangah ber ada tingkat sejahtera.

2. Saran

Sesuai dengan kesimpulan dan implikasi yang telah dikemukakan di atas, maka peneliti mencoba memberikan saran atau masukan sebagai berikut:

a. Perlu di pertimbangkan lagi pemberian izin mendirikan bangunan di atas lahan pertanian yang produktif oleh dinas tata kota dan dinas pertanian.

b. Penelitian ini perlu ditindak lanjuti lagi, agar variabel yang belum disentuh, diteliti lagi guna pembahasan yang lebih luas dan terarah.

\section{DAFTAR PUSTAKA}

Arikunto S. 2002. Metode Penelitian. Rineka Cipta. Jakarta

BPS. (2005). Indikator Kesejahteraan Rakyat 2005. BPS: Jakarta. 
BPS. (2014). Indikator Kesejahteraan Rakyat (Walfare Indicator) 2014. BPS: Jakarta.

BPS Kota Padang. (2017). Padang Dalam Angka. Padang

Eirlangga (2007). Sistem Informasi Sumberdaya Lahan. Blog

Fauzia, Lily, 1999." Pengaruh Alih Fungsi Lahan Pertanian Terhadap Sosial Ekonomi Masyarakat)". Tesis. Program
Pasca Sarjana, Universitas Sumatera Utara

Fuzah (2009). Sistem Mata Pencaharian. Blog

Sugiarto. (2003). Teknik Sampling. Jakarta.: Gramedia Pustaka Utama.

UU RI No 41 tahun 2009 tentang Perlindungan Lahan Pertanian Pangan Berkelanjutan 